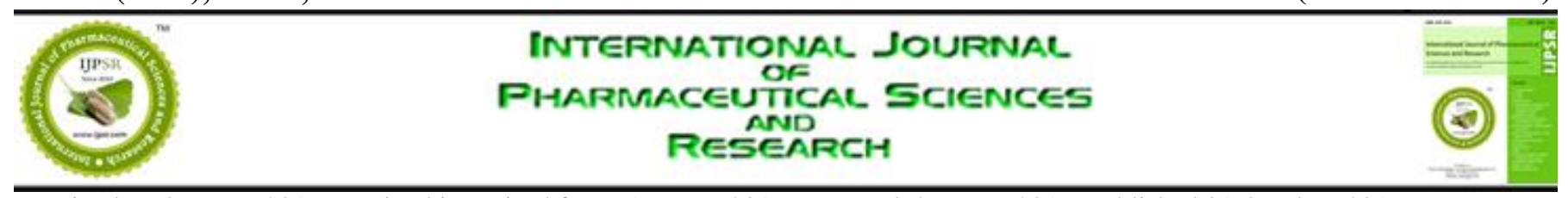

Received on 06 May, 2016; received in revised form, 17 June, 2016; accepted, 29 June, 2016; published 01 October, 2016

\title{
THE EFFECT OF PURIFIED NIGELLA SATIVA LECTIN AGAINST TUMOR DEVELOPMENT IN FEMALE ALBINO MICE AND GENETIC POLYMORPHISM IN PUMA GENE
}

Wael S. Abdel-Mageed ${ }^{* 1}$, Marwa M. Marey ${ }^{2}$ and Khalil El-Halfawy ${ }^{3}$

Lecturer of Molecular Biology ${ }^{1}$, Genetic Engineering and Biotechnology Research Institute, Sadat University, Egypt.

Science of Pharmacy ${ }^{2}$, Fac. Pha., Tanta Univ, Egypt.

Professor of Molecular Genetics 3, Genetic Engineering and Biotechnology Research Institute, Sadat University, Egypt.

Keywords:

Nigella sativa, lectin,

Tumor, Mice, PUMA, gene

\section{Correspondence to Author:}

Wael Abdel-Mageed

Molecular Biology Department,

Genetic Engineering and

Biotechnology Research Institute

(GEBRI), Sadat University, Egypt.

Email:

drwael.abdelmageed0@gmail.com

\begin{abstract}
The purpose of this study examine whether the polymorphism in p53 upregulated modulator of apoptosis (PUMA) gene consequential treated with purified Nigella sativa lectin in tumor induced mice. Nigella sativa ( $N$. sativa) is a widely used medicinal plant throughout the world. Possess a seed lectin that was purified by combination of ammonium sulfate precipitation and affinity chromatography on a Sepharose $4 \mathrm{~B}$ column. The Nigella sativa strongly agglutinated human erythrocytes. The hemagglutinating activity of lectin was maintained after incubation at a wide range of temperature and $\mathrm{pH}$ and also was independent of divalent cations. By sodium dodecyl sulfate-polyacrylamide gel electrophoresis analysis, lectin exhibited an electrophoretic profile consisting of a single band with apparent molecular mass of $45 \mathrm{kDa}$. Experimental groups were organized into 6 groups including 10 animals per each, additionally control group, blood samples were collected form mice before and after lectin treatment for liver and kidney enzymes biochemical analysis, Data statistical analysis for mitochondrial enzymes in our study showed a very highly significant $(P<0.001)$ difference in the mean value of serum enzymes isolated from treatments groups with the polymorphism of the PUMA gene were typed from genomic DNA, the results from PUMA showed a strong deferent between the treatments with lectin.
\end{abstract}

INTRODUCTION: Cancer is a metabolic disease involving disturbances in energy production through respiration and fermentation. The genomic instability observed in tumor cells. The disturbances in tumor cell energy metabolism can be linked to abnormalities in the structure and function of the mitochondria ${ }^{1}$.

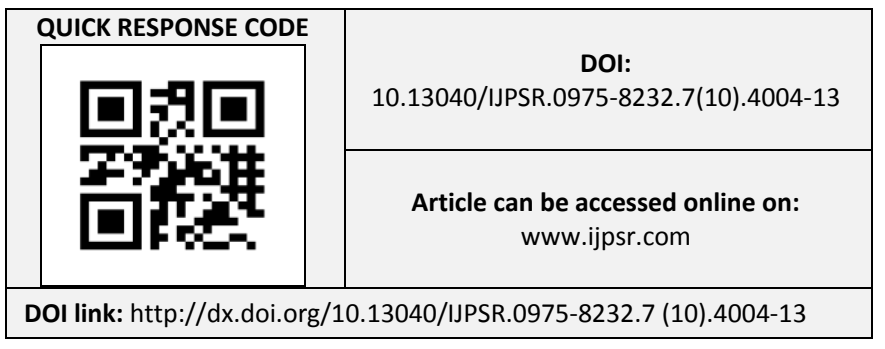

Cancers also occur in many tissues with a lot of etiologies and varying tumor progression and is one of the greatest threats to human health. Wide range of side effects of treatments such as chemotherapy and radiation on normal cells, it is necessary to develop safer and noninvasive treatments ${ }^{2,3}$. Plant lectins are bioactive glycoproteins possessing carbohydrate-recognition domain ${ }^{4}$.

It can be divided into groups, such as mannosebinding, glucose/ mannose-binding, Nacetyl glucosamine-binding, galactose - binding, Nacetyl galactosamine-binding, fucose-binding, and sialic acid-binding, according to their carbohydrate- 
binding specificity. Lectins are present in a diversity of organisms including microorganisms, flowering plants, animals, fungi, and bacteria ${ }^{5}$, and have attracted great interest due to their varied physiological roles in cell agglutination, antitumour, immunomodulatory, antiproliferative, antitumor, antifungal and antiviral effects ${ }^{5,6}$. They serve as powerful tools in immunological studies and can be employed as immunohistochemistry markers in diagnosis of cancer and profiling of cell surface types due to expression of aberrant glycans on diseased and transformed cells ${ }^{4}$.

The biological function of these proteins is quite varied, including adhesion, migration, proliferation, and differentiation of cells. Due to their ability to specifically bind hydrocarbons to carbons on the cell surface, many lectins have potential roles in cancer and metastasis ${ }^{7}$. Serum biomarkers are promising clinical prognostic elements in growth patients. In any case, single biomarker might not have adequate prescient force for clinical application. Liver capacity tests (LFTs) including alanine aminotransferase (ALT) and soluble phosphatase (ALP) have significant part in malignancy forecast. There is expanding enthusiasm for utilizing Liver capacity tests (LFT) variables as free indicators of non-liver ailment related dreariness and mortality in overall public and growth patients. A couple concentrates on have explored the associations of LFTs with mortality in bosom tumor ${ }^{8}$. Raised Alanine aminotransferase (ALT) and basic phosphatase (ALP) are auxiliary to intrahepatic or extrahepatic deterrent, cholestasis from pharmaceutical, or infiltrative infection (e.g., malignancy or granulomas). Renal capacity tests (RFTs) including serum creatinine (sr.cr.) and urea level have critical part in tumor anticipation.

There was an exceedingly critical increment in serum urea fixation in tumor-bearing mice, such increment in blood urea focus to catabolic impact of tumor and the increase in urea creation. Furthermore critical expansion serum creatinine level in tumor-bearing mice because of muscle rot 9 . Autophagy is a critical segment in lectin research as a component for restraining neoplastic development. In spite of the fact that this survey is concerned for the most part the systems of apoptosis induction, it is vital to consider the conceivable outcomes autophagy presents in lectin malignancy therapy ${ }^{10}$. PUMA mediates apoptosis thanks to its ability to directly bind known antiapoptotic members of the Bcl-2 family. It mainly localizes to the mitochondria. The binding of PUMA to the inhibitory members of the Bcl-2 family (Bcl-2-like proteins) via its $\mathrm{BH} 3$ domain seems to be a critical regulatory step in the induction of apoptosis. It is normally expressed at a low level but is markedly induced after cells are exposed to DNA-damaging agents, such as chemotherapeutic drugs and ionizing radiation ${ }^{11}$. The present study aimed to investigate the effect of lectin from black seeds on the development of experimental tumor induced by the administration of DMBA (7, 12 dimethyl benza[a]anthracene) in mice.

\section{MATERIAL AND METHODS:}

Nigella sativa seeds were used for all the experiments in this study, purchased from the NRC, Egypt. Typed human blood cells (A, B, and $\mathrm{O})$ were obtained from healthy donors. All other reagents were either of analytical grade or of the highest quality available.

\section{Extraction of and Purification Lectin:}

The seeds (50 g) was broken into pieces (approx. $1 \mathrm{~mm})$, added to a 10 -fold volume $(150 \mathrm{ml})$ of $50 \mathrm{mM}$ phosphate buffer ( $\mathrm{pH} 7.4)$ and extracted at 4 ${ }^{\circ} \mathrm{C}$ for $16 \mathrm{~h}$. Supernatant obtained by centrifugation (8000rpm for 20min) was then used for lectin purification. Proteins in the supernatant were fractionated by ammonium sulfate precipitation (30-90\% saturation). The precipitate was resuspended and dialyzed extensively against $50 \mathrm{mM}$ phosphate buffer (PBS $\mathrm{pH}$ 7.4) before applied to affinity chromatography on a Malt amyl sepharose $4 \mathrm{~B}$ column $(10 \times 1.5 \mathrm{~cm})$ pre-equilibrated with the same buffer and eluted with 1M Maltose buffer. The fractions which showed absorbance at $280 \mathrm{~nm}$, were collected and dialyzed extensively against $50 \mathrm{mM}$ PBS at $4^{\circ} \mathrm{C}$ overnight to remove Maltose. Protein concentration was measured for those fractions according to O.D.

\section{Preparation of RBC Suspension:}

For human red blood cells (RBC) preparation, the extracted RBC were centrifuged at $500 \mathrm{~g}$ for $5 \mathrm{~min}$, and then washed with PBS three times, and diluted 
to a $2 \%$ RBC suspension. The diluted $\mathrm{RBC}$ suspension (in PBS, $10 \mathrm{ml}$ ) was treated with $1 \mathrm{ml}$ neuraminidase $(100 \mu \mathrm{g} / \mathrm{ml})$ for $1 \mathrm{~h}$ at $37^{\circ} \mathrm{C}$. Then the cells were washed by buffer PBS three times $^{12}$.

\section{Hemagglutination Assays:}

Hemagglutination assays (HA) were performed in $\mathrm{V}$ bottom microtiter plates according to the method described by ${ }^{13}$ The HA titers were recorded as the reciprocal of the highest dilution of the sample causing complete agglutination of RBC. Control was substituted the sample by $50 \mathrm{mM}$ PBS, pH 7.2. The HA assay was repeated three times.

\section{Protein Electrophoresis:}

The purity of the lectin during the purification steps was tested by SDS-PAGE according to the procedure of ${ }^{14}$, using $12 \%$ total concentration polyacrylamide as the separating gel and $4 \%$ polyacryl-amide as the stacking gel. The molecular weight of PN-L was determined by SDS-PAGE under reducing and non-reducing conditions. The separated proteins were stained with Comassie Brilliant Blue R-250. The protein concentration of the different samples was determined through the method of Bradford, using BSA (bovine serum albumin) as standard.

\section{Animals and experimental design:}

The experiment was performed on female albino mice (weighing about $20 \mathrm{~g}$ ). Animals were housed in polypropylene cages in group of 10 with $12 \mathrm{~h}$ dark and light cycles at the temperature $20 \mathrm{C}$ to $30 \mathrm{C}$ with relative humidity between $75 \%$ and $85 \%$. The animals were given laboratory animal feed approximately $15 \mathrm{~g} /$ mice daily $^{15}$. All groups were injected $(100 \mu 1 /$ mice daily dose) for a period of 18 days.

Group I: (Master) (M): mice of this group did not injected by anything.

Group II: (Healthy Control) (gp C): mice of this group injected S.C. by $0.5 \mathrm{M}$ maltose solution.

Group III: (Healthy Control) (gp L): mice of this group injected S.C. by Lectin solution $100 \mu$ l of Lectin solution contain $0.053 \mathrm{mg}$ Lectin.
Group IV: (Protection group) (gp B). Mice of this group injected S.C. by Lectin solution $(100 \mu 1 /$ mice daily dose) and in the $8^{\text {th }}$ day tumor was induced in mice by injecting DMBA (7, 12 dimethyl benza[a]anthracene) S.C. $(700 \mu 1 /$ mice only one dose). $700 \mu \mathrm{l}$ of DMBA solution contain $7 \mathrm{mg}$ DMBA. Lectin injection continued for 10days after tumor induction. DMBA solution prepared by dissolving $100 \mathrm{mg}$ of DMBA powder in $5 \mathrm{ml}$ PBS (PH 7.4), $1 \mathrm{ml}$ ethanol, $0.5 \mathrm{ml}$ acetone and $3.5 \mathrm{ml}$ oil.

Group V: (Late stage treatment group) (gp A). This group tumor was induced in mice by injecting DMBA (7, 12 dimethyl benza[a]anthracene) S.C. (700 $\mu 1 /$ mice only one dose). $700 \mu 1$ of DMBA solution contain $7 \mathrm{mg}$ DMBA. Treatment therapy of Lectin began after 11days of tumor induction. Lectin treatment therapy involved Lectin injection S.C. $(100 \mu 1 /$ mice daily dose) for a period of 16 days.

Group VI: (Early stage treatment group) (gp A*). This group tumor was induced in mice by injecting DMBA (7, 12 dimethyl benza[a]anthracene) S.C. (700 $\mu 1 /$ mice only one dose). $700 \mu 1$ of DMBA solution contain $7 \mathrm{mg}$ DMBA. Treatment therapy of Lectin began after 3days of tumor induction. Lectin treatment therapy involved Lectin injection S.C. $(100 \mu 1 /$ mice daily dose) for a period of 8 days. At the end of experiment all mice were sacrificed. Mice were sacrificed and their body weights were recorded. Internal organs (lung, liver, kidney, heart and spleen) and tissue (breast and tumor) was collected carefully.

\section{Determination of Therapeutic Effect in mice Tumor Models:}

Regardless of whether survival data or tumor measurements are the primary end points, mice should be weighed throughout the course of the experiments, as body weight provides another means of assessing toxicity, usually done in terms of percentage change of body weight from the weight at start of the experiment. Tumors should be measured beginning when they are first palpable: the length ( $\mathrm{L}=$ longest dimension), the width (W= the distance perpendicular to and in the same plane as the length), and the height $(\mathrm{H}=$ the distance between the exterior tumor edge and the mouse 
body). The ellipsoid volume of the tumor, calculated from

$0.5 \times \mathrm{L} \times \mathrm{W} \times \mathrm{H}$ provides the most accurate measure of tumor mass.

\section{Blood sampling collection:}

The mice tail immersed in $42{ }^{\circ} \mathrm{C}$ water for $40-50$ sec to dilate blood vessels and dry the tail with a paper towel. Target either the left and right tail veins that lie lateral to the artery. Blood serum was collected by placing samples (without anticoagulant) at room temperature for up to 30 min to enable clotting. Spin the collection tubes in a refrigerated centrifuge $\left(4{ }^{\circ} \mathrm{C}\right)$ at $2,000 \mathrm{x} \mathrm{g}$. The serum may then be eluted ${ }^{16}$.

\section{Biochemical analysis:}

The serum was collected and stored at $-20^{\circ} \mathrm{C}$ for less than a week until being analyzed for urea and creatinine as indicators of kidney function, and for alkaline phosphatase and alanine aminotransferase (ALT) as indicators of liver function. All Biochemical analyses were performed according to the International Federation of clinical chemistry (IFCC) ${ }^{17}$ by using reagent kits obtained from spectrum diagnostic, Egypt.

\section{DNA isolation from tissue samples:}

DNA was isolated from internal organs and tissue using ZYMO kit.

\section{Gel electrophoresis to analyze DNA quality:}

Agarose gel electrophoresis can be used to assess the intactness of purified DNA. 1\% agarose gel (0.5g agarose) was prepared in 50ml $1 \mathrm{X}$ TBE (Tris, Boric Acid, EDTA) buffer containing $2 \mu$ l ethidium bromide.

\section{Gene polymorphism - polymerase chain reaction:}

The puma polymorphism was screened by thermocycler PCR system. A PCR assay was performed with PCR master mix (10× buffer, $\mathrm{MgCl} 2$ and dNTPs and Taq DNA polymerase).

\begin{tabular}{|c|c|c|}
\hline SNP & Primer sequence (5'-3') & Cycling conditions \\
\hline puma & $\begin{array}{l}\mathbf{F}: \text { CAACTAGGTGCCTACACCCG } \\
\mathbf{R}: \text { AGGAGGCTAGTGGTCAGGTT }\end{array}$ & 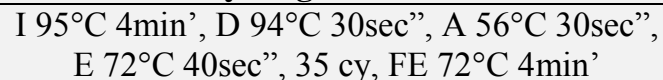 \\
\hline
\end{tabular}

Amplified samples were digested with the specific restriction enzyme $5 \mu \mathrm{L}$ of amplified PCR product, $0.5 \mu \mathrm{L}$ of restriction enzyme (HapII), $2 \mu \mathrm{L}$ of enzyme buffer, $12.5 \mu \mathrm{L}$ of sterile distilled water to obtain $20 \mu \mathrm{L}$ total reaction volume incubated at $37^{\circ} \mathrm{C}$ in heat block for $30 \mathrm{~min}$.

\section{Statistical analyses:}

Significant differences between means of experiments were determined by least significant difference. SPSS17.0 statistical tool was used to analyze the data obtained.

\section{RESULTS:}

\section{Purification of Lectin:}

Purification of the lectin from the seed of Nigella sativa was achieved by one chromatographic step, with a Sepharose 4B column. The unretained fraction was eluted with Maltose buffer. The elution had hemagglutinating activity in the presence of tested erythrocytes. Lectin crude extraction was applied to the column and on elution with Maltose in PBS yielded $530 \mu \mathrm{g}$ of pure lectin. The specific activity of lectin was increased compared to that of the crude extraction. Analysis of purified lectin on SDS-PAGE in the absence of Maltose revealed a single band at $45 \mathrm{kDa}$ (Fig. 1).

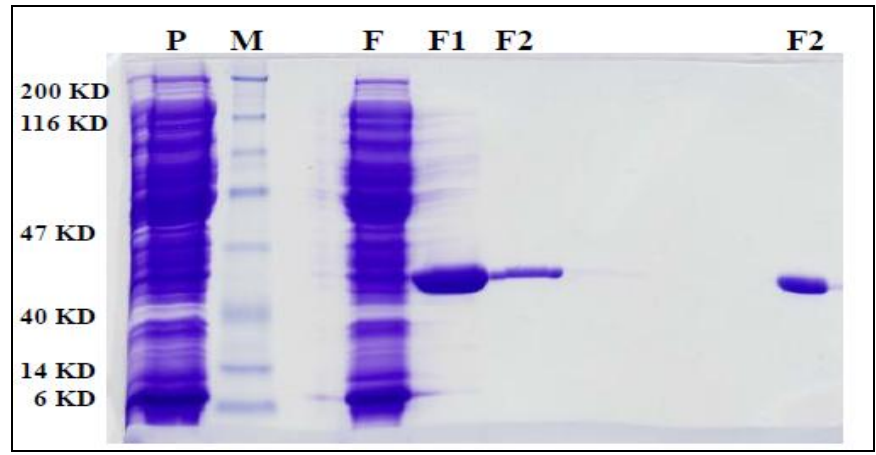

FIG.1: ELECTROPHORETIC ANALYSIS OF LECTIN FROM NIGELLA SATIVA

SDS-PAGE of Lectin from Nigella sativa affinity chromatography (12\%) lane P; plant extract, lane M: Marker, lane F: flow throw lane F1 and F2; first purification. 


\section{Body Weight:}

Tumor-Free Groups: Injection with maltose result in weight gain of animals, while administration of lectin showed $20 \%$ weight loss compared to the control.

Tumor Bearing Groups: A significant weight loss was observed upon administration of lectin in protection (B) and treatment groups ( $\mathrm{A}$ and $\mathrm{A}^{*}$ ) by $8 \%, 38 \%$ and $5 \%$ respectely.

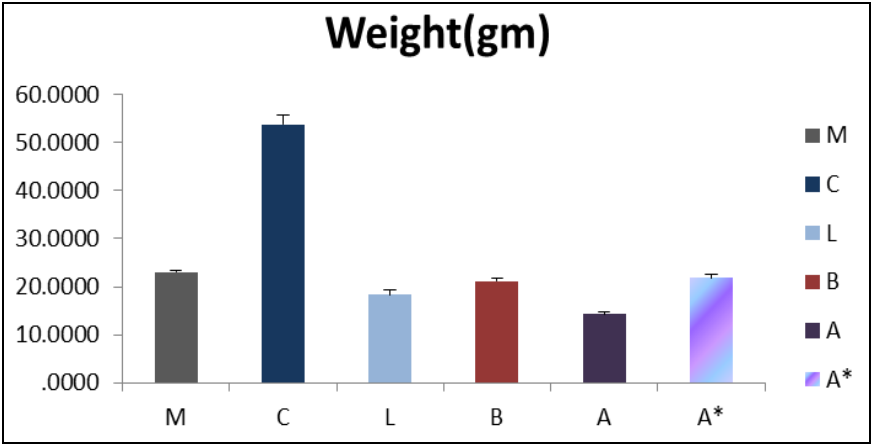

FIG. 2: MEAN WEIGHTS (GM) OF MICE OF THE VARIOUS GROUPS TREATED WITH LECTIN EXTRACTED FROM N.SATIVA SEEDS. Values are expressed as mean \pm S.E of six mice in each group.

\section{Tumor Volume:}

Compared to the tumor groups, lectin injections resulted in reductions in tumor volume. In group B tumor was measured after 5 days from tumor induction and at the end of experiment which shows $82 \%$ reduction in tumor volume. Group A shows $97 \%$ reduction in tumor volume between tumor volume before lectin injection (after 10 days from tumor induction) and at the end of experiment (after treatment with lectin). While Group A* shows $87 \%$ reduction in tumor volume between tumor volume after 5 days from tumor induction and at the end of experiment (after treatment with lectin).

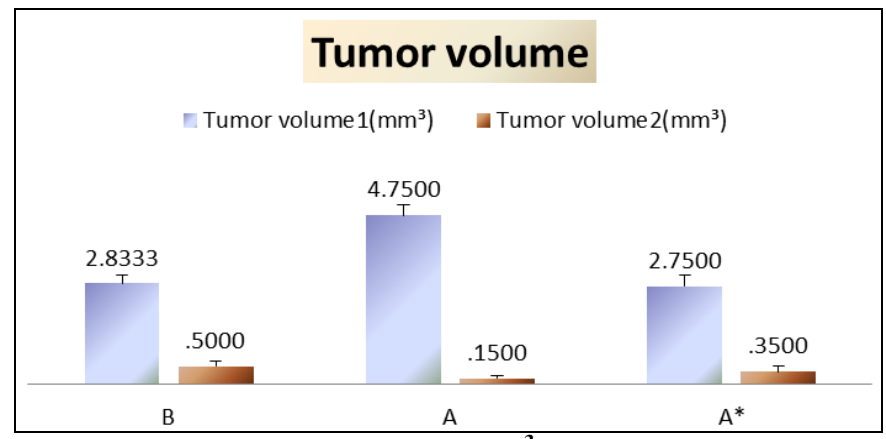

FIG. 3: TUMOR VOLUME $\left(\mathrm{mm}^{3}\right)$ OF MICE OF THE VARIOUS GROUPS TREATED WITH LECTIN EXTRACTED FROM N.SATIVA SEEDS.
Values are expressed as mean \pm S.E of six mice in each group. tumor volume1 refer to mean values of tumor volume $\left(\mathrm{mm}^{3}\right)$ during the experiment, Tumor volume2 refer to mean values of tumor volume $\left(\mathrm{mm}^{3}\right)$ at the end of experiment.

\section{Biochemical analysis results:}

Levels of serum ALT: Data represented in Fig. 4 show the statistical analysis and mean values of ALT levels in the serum of different groups of the present study. The serum concentration of ALT increased significantly $(\mathrm{p}<0.001)$ mostly in animals of group A during and at the end of experiment, compared to the control.

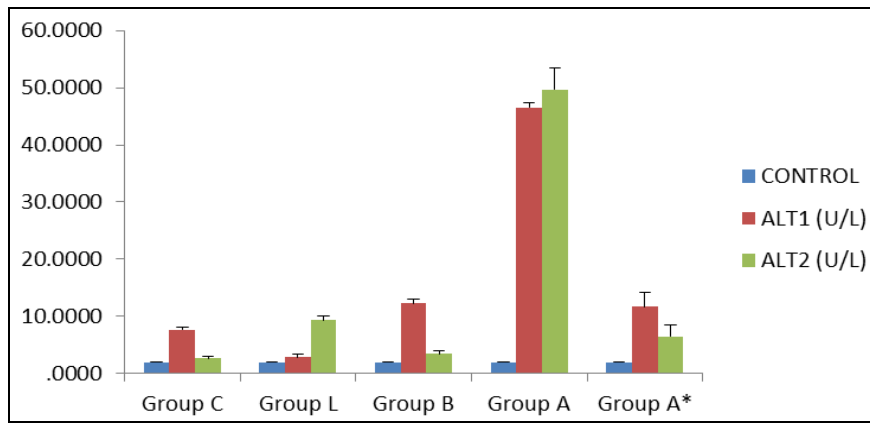

FIG. 4: LEVEL OF ALT (IU/L) IN THE MICE SERUM OF DIFFERENT GROUPS.

Values are expressed as mean \pm S.E of six mice in each group. AlT1refer to mean values of serum AlT during the experiment, AlT2 refer to mean values of serum AlT at the end of experiment.

\section{Level of serum alkaline phosphatase (AIP)} activity:

Data represented in Fig. 5 show the statistical analysis and mean values of AIP levels in the serum of different groups of the present study. A significant increase $(\mathrm{p}<0.001)$ was observed in all the groups during and at the end of experiment, compared to the control. Group A* show some difference, serum AlP increased during the experiment and then decreased again at the end of experiment.

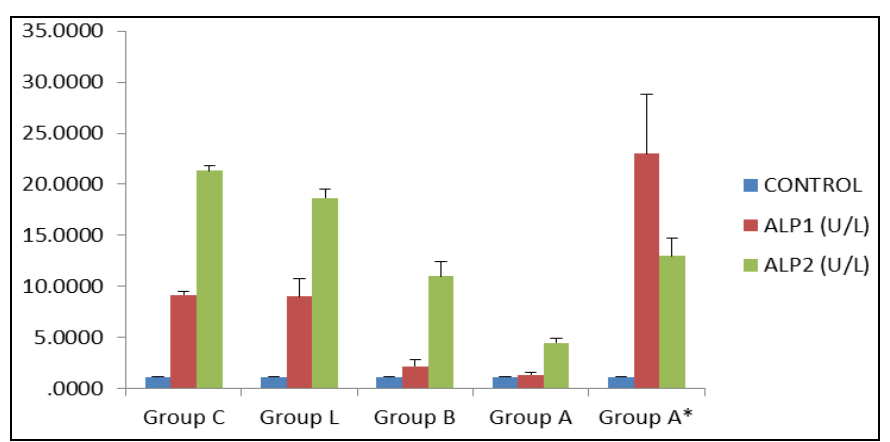

FIG. 5: LEVEL OF ALP (IU/L) IN THE MICE SERUM OF DIFFERENT GROUPS. 
Values are expressed as mean \pm S.E of six mice in each group. AlP1refer to mean values of serum AlP during the experiment, AlP2 refer to mean values of serum AlP at the end of experiment.

\section{Levels of serum urea:}

Data represented in Fig. 6 show the statistical analysis and mean values of urea levels in the serum of different groups of the present study. A significant increase $(p<0.001)$ was observed in all the groups during and at the end of experiment, compared to the control. The serum concentration of urea increased significantly $(\mathrm{p}<0.001)$ mostly in animals of group A at the end of experiment, Group $A^{*}$ show some difference, serum urea increased during the experiment and then decreased again at the end of experiment.

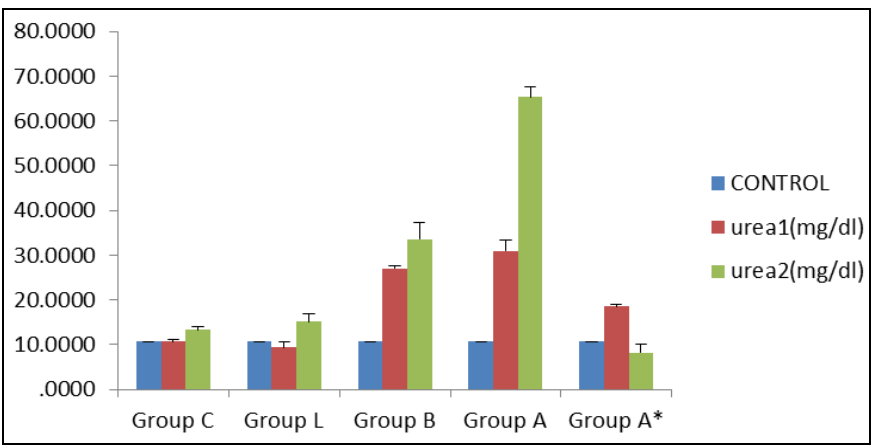

FIG. 6: LEVEL OF UREA IN THE SERUM OF DIFFERENT ANIMAL GROUPS. Values are expressed as mean \pm S.E of six mice in each group. urea1refer to mean values of serum urea during the experiment, urea2 refer to mean values of serum urea at the end of experiment.

\section{Levels of serum creatinine:}

Data represented in Fig.7 show the statistical analysis and mean values of creatinine levels in the serum of different groups of the present study.

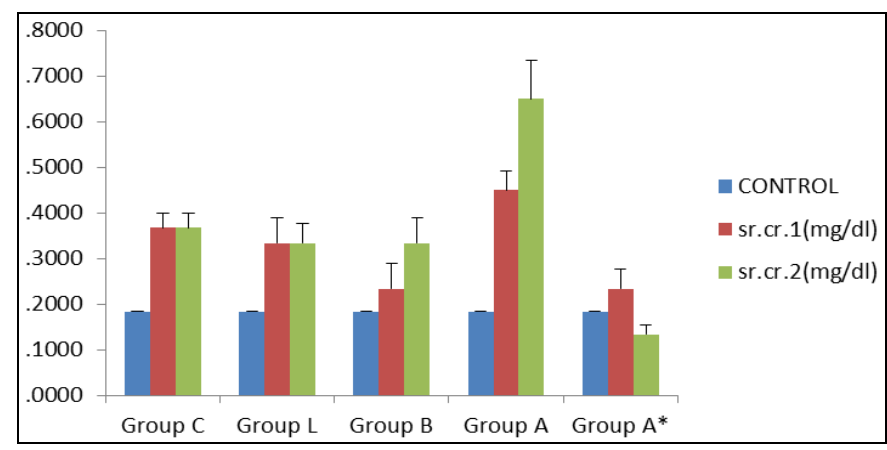

FIG. 7: LEVEL OF CREATININE IN THE SERUM OF DIFFERENT ANIMAL GROUPS. Values are expressed as mean \pm S.E of six mice in each group.sr.cr.alrefer to mean values of serum creatinine during the experiment, sr.cr.2 refers to mean values of serum creatinine at the end of experiment.
A significant increase $(\mathrm{p}<0.005)$ was observed in all the groups during the experiment, compared to the control. The serum concentration of creatinine increased significantly $(\mathrm{p}<0.001)$ mostly in animals of group $A$ at the end of experiment, group $A^{*}$ show some difference, serum creatinine increased during the experiment and then decreased again at the end of experiment.

\section{Molecular studies:}

DNA extracted from liver of different animal groups and after agarose gel electrophoresis of DNA extracted. Results showed all groups have a good extracted DNA there is no difference observed between different groups except (M) negative group and (C) normal control group. PUMA progresses through identifiable phases, which are differentially sensitive to treatments intervention. Therefore; we treated mice with the lectin after tumor induction according to standard protocol and used lectin as a protective against the tumor effects as well.

To explore the functional relevance of the polymorphisms in PUMA functional gene, we used the Restriction enzymes method to determine PUMA expression different in genomic DNA treated mice for the genotype-phenotype correlation analysis between different protective treated of the two polymorphisms. In this analysis, the genotype was associated with the kind of treatment, the protective lectin and the expression level with HpaII digested (restriction enzyme that cuts DNA at this recognition site: $\mathrm{C}^{\wedge} \mathrm{CGG}$ ), (Fig. 8). To determine the potentially differential regulation of the PUMA activity, we further performed the digestion to verify whether these polymorphisms may change the activity of PUMA.

We found there is no changing in the $M$ group and $\mathrm{C}$ group with PUMA gene pattern and strong change with the HpaII digestion with the other groups, indicating a potentially different activity affinity of PUMA protein structure polymorphism. These results might only suggest a potentially functional correlation between the lectin, tumor and PUMA expression and might not indicate the exact changes of PUMA nucleotide sequences. Therefore, further functional studies for the correlation between epigenetics and lectin effects 
are needed to elucidate how and what extent of lectin effects on tumor progression.

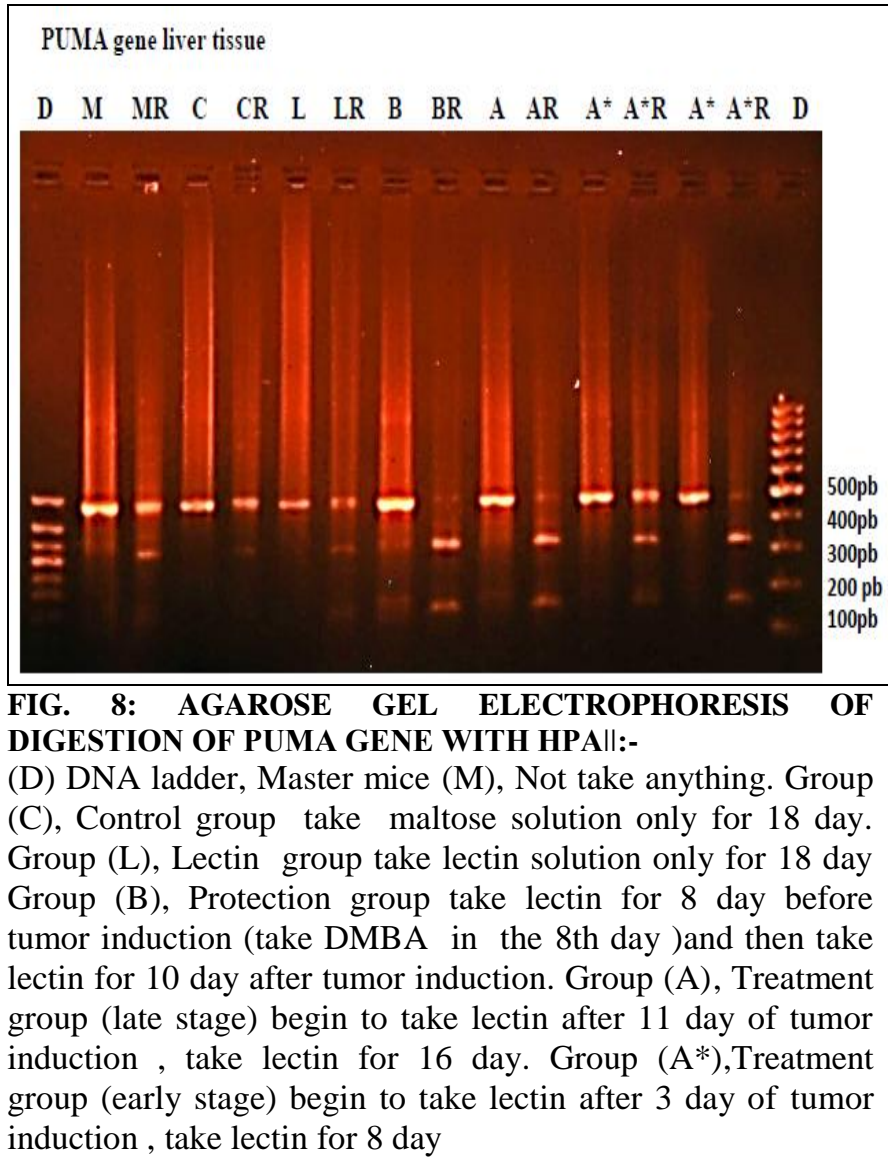

DISCUSSION: The presence of naturally occurring lectins in the haemolymph of several plants has been well known since the beginning of the 20th century. Most current research has emphasized the biochemical applications of lectins, because of their anticancer properties and potential application as antitumor agents. Lectins have become the focus of intense interest for biologists and in particular for the research and applications in agriculture and medicine ${ }^{6,18}$.

In the present study, a new lectin was purified from the seed of Nigella sativa by affinity chromatography. SDS-PAGE analysis revealed one band with a molecular mass of $45 \mathrm{kDa}$. This agglutinin appeared to be a C-type agglutinin, as $\mathrm{Ca} 2+$ is required for its HA activity and it was reversibly sensitive to EDTA. The lectin specific activity was increased many fold following purification ${ }^{6}$, Jaguar is initiated by translation elements because of anxiety, prompting apoptosis induction and tumor concealment. DNA harm or enacted oncogenes actuates PUMA through p53 to advance apoptosis. Incendiary cytokines instigates PUMA to advance apoptosis. DNA harm, provocative cytokines and maybe yet-to-be recognized go be tweens and translation variables (TF), PUMA-subordinate apoptosis amid irritation, PUMA genes and the defensive part of lectin in mice tumor incited and connection with physiological enzymes.

Alanine transaminase, (ALT) and aspartate transaminase are compounds that assistance in metabolism of protein. At the point when the liver is harmed, ALT is expanded in liver and discharged in the circulation system. An expansion in AST levels might show liver harm or infection. Aspartate transaminase is the mitochondrial protein, prevalently found in the liver, skeletal muscles and kidneys. ALT is a cytosolic compound, which is more particular for the liver than aspartate transaminase ${ }^{19}$.

In our study, Monitoring body weight and tumor volume have been used to assess the effect of the applied doses of lectin on tumor induced in mice model. Body weight shows reduction in all groups treated with lectin. The present results reporting significant reductions in tumor volumes of animals treated with lectin, which resulted in an almost complete disappearance of the tumor $(90 \%$ of original volume), that proved the antimetastasis effect of the lectin of Nigella sativa.

The present results show that there was a highly significant difference in the parameters of biochemical analysis among groups $<0.001$ in all ALT concentration compared with the control group and there was high level produced specifically with group A. Transaminases are the metabolic enzymes which collect the amino groups from many different amino acids in the form of only one C-glutamate. The glutamate channels amino groups either into biosynthetic pathways or into a final sequence of reactions by which nitrogenous waste products are formed and then excreted ${ }^{20}$. Serum alkaline phosphatase (AIP) is an enzyme found in bloodstream. ALP helps break down proteins in the body and exists in different forms, depending on where it originates. It is mostly produced in liver, High Levels than normal 
levels of ALP in your blood may indicate a problem with liver or gall bladder. This could include cirrhosis (scarring), liver cancer, gallstones, the statistical analysis and mean values of AlP levels in the serum of different groups of the present study. A significant increase $(\mathrm{p}<0.001)$ was observed in all the groups during and at the end of experiment, compared to the control.

Group A* show some difference, serum AlP increased during the experiment and then decreased again at the end of experiment. Lectin and maltose caused significant in liver enzymes. However, phosphate enzymes act by hydrolyzing phosphomonoester including 3, and 5, phosphoproteins and these may also be involved in the transfer of phosphate, phosphatases are involved in many different processes that require mobilization of phosphate ion or dephosphorylating as part of anabolic, catabolic or transfer processes ${ }^{5}$, 10

In the present study, the increased level of phosphatases and aminotransferases in blood may be indicate to metabolic activity, perhaps to meet the stress induced by prolonged exposure to the tumor. The functional capacity of the kidney can be measured by the dye excretion tests, clearance test, concentration and dilution tests and method for examination of blood concentrations of excretory and electrolyte constituents. Furthermore, renal function tests are required either to demonstrate the presence or absence of active lesion in the kidney, or to assess the normal functioning capacity of different parts of the functioning unit, nephron.

However, urea is the major nitrogen-containing metabolic product of protein catabolism. A significant increase $(\mathrm{p}<0.001)$ was observed in all the groups during and at the end of experiment, compared to the control. The serum concentration of urea increased significantly $(\mathrm{p}<0.001)$ mostly in animals of group A at the end of experiment, Group $A^{*}$ show some difference, serum urea increased during the experiment and then decreased again at the end of experiment. The creatinine, another product of protein metabolism from the start of administration to half the control value by the end of administration may be an indication of compromise of the renal function. Lectin might have adversely interfered with the metabolism of creatinine leading to significance increase $(p<0.005)$ was observed in all the groups during the experiment, compared to the control. The serum concentration of creatinine increased significantly $(p<0.001)$ mostly in animals of group A at the end of experiment, group $A^{*}$ show some difference, serum creatinine increased during the experiment and then decreased again at the end of experiment.

The various alterations in the functional indices of the tissues and their values which do not compare favorably with their control values are clear manifestation of adverse effects of the functional parameters evaluated following the daily administration of the aphrodisiac. This study suggests that lectin administration has good effect on the basic functions of the liver and kidney investigated. These enzyme changes are indicative of the cellular toxicity and tissue damage induced by tumor effect in the mice probably by altering the specific molecular pathways. This is concomitant with results obtained. In this study, we found that there is polymorphism in digestion of PUMA genes. Result showed a strong deferent between the different groups treated with lectin, Apoptosis constitutes one of the main safeguards against carcinogenesis. Deregulated apoptosis in the extrinsic or intrinsic pathway is a leading characteristic of development of human cancer ${ }^{11}$. The Bcl-2 family is one of the real controllers of the mitochondrial pathway of apoptosis. Mutual quantitative regulations and a fitting harmony in the middle of genius and hostile to apoptotic proteins give tissue homeostasis. Our study demonstrated a hereditary polymorphism in liver PUMA quality under treatment with various medicines. This polymorphism prompts produce abnormal PUMA protein. The down regulation or overexpression of proteins that advance survival or loss of apoptogenic variables is connected with tumor improvement ${ }^{21}$.

A substantial number of results have demonstrated that PUMA brokenness happens in numerous growth sorts. There is frequently a complete discernible absence of PUMA expression connected with change or deletion of p53. Loss of p53, which goes about as a translation element, is affirmed in more than $50 \%$ of human tumors. The 
consequence of such occasions is the aggregate cancelation of PUMA prompting expression, and in this manner, the resistance of tumor cells to chemotherapeutic agents ${ }^{22}$. The lack of PUMA expression in cells experiencing neoplastic change can likewise be caused by complete cancellation of the long arm of chromosome 19 (19q13.3), where the quality encoding this protein is found. Such distortions were accounted for on account of gliomas, neuroblastomas, certain sorts of B-cell lymphomas, and head and neck tumors ${ }^{21,23}$.

CONCLUSION: Lectin was purified from black (Nigella sativa) seed. From affinity chromatography bounded proteins are collected. Lectin aggregation used to study for hemagglution activity of human RBC. The activity of agglutination exhibit with respect to crude, $30 \%$, $90 \%$ saturation and affinity portion. In SDS PAGE clearly distinct band corresponding to $45 \mathrm{kDa}$ in the affinity portion. From the experiment we confirmed our isolated lectin. Then we study the effect of purified Nigella sativa lectin against tumor development in female albino mice which give very encouraging results in groups that take lectin as a protection from cancer or as a treatment groups.

The results showed on the biochemical and molecular level. The purified lectins are identically from the molecular weight $45 \mathrm{kDa}$ in the process of SDS PAGE. Nigella sativa lectin aggregation used to study for relationship between cell toxicity and aggregation process. It can be used as therapeutic drug for future references. It cross-links cell surface glycoproteins, thereby initiating various cellular responses, including $\mathrm{T}$-cell activation and trigger apoptosis pathway in cancer cells.

\section{REFERENCES:}

1. Seyfried T N, Flores R E, Poff A M and D'Agostino D P: Cancer as a metabolic disease: implications for novel therapeutics. Carcinogenesis2014; 00(oo): 1-13.

2. Yan S, Li Y Z, Zhu X W, Liu C L Wang P and Liu Y L: HuGE systematic review and meta-analysis demonstrate association of CASP-3 and CASP-7 genetic polymorphisms with cancer risk. Genetics and Molecular Research 2013; 12(2): 1561- 1573.

3. Halaby R: Triptolide: Novel Anticancer Agent for Chemoresistant Cancer Cells that are Caspase-3 Deficient. Journal of Molecular Biology and Molecular imaging 2014; 1(3): 1-8.
4. Majee S B and Biswas G R: Exploring plant lectins in diagnosis, prophylaxis and therapy. Journal of Medicinal Plants Research 2013; 7 (47): 3444-3451.

5. Patel A: Isolation, characterization and production of a new recombinant lectin protein from leguminous plants. Biochemical Compounds 2014; 2(2): 1-9.

6. Hamid R, Masood A, Wani I H and Rafiq S: Lectins: Proteins with Diverse Applications. Journal of Applied Pharmaceutical Science 2013; 3(4): S93-S103.

7. Pohleven J, Strukelj B and Kos J: Affinity Chromatography of Lectins. In: Affinity Chromatography.( S. Magdeldin Ed.) Science, Technology and Medicine open access publisher, InTech 2012: 49-74.

8. Liu X, Meng Q H, Ye Y, Hildebrandt M T, Gu J and Wu $\mathrm{X}$ : Prognostic significance of pretreatment serum levels of albumin, LDH and total bilirubin in patients with nonmetastatic breast cancer. Carcinogenesis 2015; 36(2): 243-248.

9. Abou Zaid O A, Hassanein M R, EL-Senosi Y A and ELShiekha M F: Ameliorative effect of curcumin and tannic acid on tumor-induced in female mice. Benha Veterinary Medical Journal 2011; (1): 61-69.

10. Yau T, Dan X, Ng C W and Ng T B: Lectins with Potential for Anti Cancer Therapy. Molecules 2015; 20: 3791-3810.

11. Zhou Z, Sturgis E M, Liu Z, Wang L E, Wei Q and Li G: Genetic Variants of a BH3-Only Pro-Apoptotic Gene, PUMA, and Risk of HPV16-Associated Squamous. Cell Carcinoma of the Head and Neck. Molecular Carcinogensis 2012; 51: E54- E64.

12. Sun J, Bi J, Zhang C, Yu L and Zhu F: Purification and Identification of a Natural Lectin from the Seed of Peanut Arachis hypogaea. Materials Scienc Journal 2011; 5: 7882.

13. Zacour M, Ward B J, Brewer A, Boivin G et. al., Standardization of Hemagglutination Inhibition Assay for Influenza Serology Allows for High Reproducibility between Laboratories._Clin Vaccine Immunol 2016; 23(3): 236-242.

14. Biswas M and Sana N K: Isolation, identification and Partial Purification of Lectin from Typhonium trilobatum. IOSR Journal of Pharmacy and Biological Sciences (IOSR-JPBS) 2014; 9(3): 41-46.

15. Bera A K, Rana $T$, Das $S$, Bhattacharya D, Pan D, Bandyopadhyay S and Das S K: Mitigation of arsenicmediated renal oxidative stress in rat by Pleurotus florida lectin. Human and Experimental Toxicology 2010; 30(8): 940-951.

16. Lee $\mathrm{G}$ and Goosens K A: Sampling Blood from the Lateral Tail Vein of the Rat. J. Vis. Exp. 2015; (99) e52766.

17. Burtis C A, Ashwood E R and Bruns D E: Tietz Textbook of Clinical Chemistry and Molecular Diagnostics, 5e, Elsevier Science Health Science 2011.

18. Pervin M, Koyama Y, Isemura M and Nakamura Y: Plant Lectins in Therapeutic and Diagnostic Cancer Research. International Journal of Plant Biology \& Research 2015; 3(2): 1030.

19. Robertson F P, Bessell P R et. al.: High serum Aspartate transaminase levels on day 3 post liver transplantation correlates with graft and patient survival and would be a valid surrogate for outcome in liver transplantation clinical trials. Transpl Int 2016; 29(3): 323-330.

20. Takamori S: Vesicular glutamate transporters as anion channels? Pflugers Arch 2016; 468(3): 513-518.

21. Vousden K H and Prives C: Blinded by the Light: The Growing Complexity of p53. Cell 2009; 137: 413-431. 
22. Nakona K: PUMA, a novel proapoptotic gene, is induced by p53. Mol. Cell. 2001; 7: 683-694.
23. Jeffers J R, Parganas E, Lee Y et.al. : Puma is an essential mediator of p53-dependent and -independent apoptotic pathways. CANCER CELL 2003; 4: 321-328.

How to cite this article:

Abdel-Mageed WS, Marey MM and El-Halfawy K: The Effect of Purified Nigella Sativa Lectin against Tumor Development in Female Albino Mice and Genetic Polymorphism In Puma Gene. Int J Pharm Sci Res 2016; 7(10): 4004-13.doi: 10.13040/IJPSR.09758232.7(10).4004-13.

All @ 2013 are reserved by International Journal of Pharmaceutical Sciences and Research. This Journal licensed under a Creative Commons Attribution-NonCommercial-ShareAlike 3.0 Unported License.

This article can be downloaded to ANDROID OS based mobile. Scan QR Code using Code/Bar Scanner from your mobile. (Scanners are available on Google Playstore) 